\title{
Prediction of Canola Seed Longevity in the Drying
}

\section{Process}

\author{
Armando Kazuo Fujii, José Tadeu Jorge and Juliana Aparecida Fracarolli \\ Department of Post-Harvest Technology, School of Agricultural Engineering, University of Campinas, Campinas 13083-875, SP, \\ Brazil
}

\begin{abstract}
The probit analysis has been an important tool to predict seed longevity during storage and has been applied for seed drying simulation. Sealed aluminum pouches containing approximately $50 \mathrm{~g}$ of canola seed at moisture range of $7 \%$ to $21 \%$ of water content web basis (\%) were conditioned in water-bath at 50, 60 and $70{ }^{\circ} \mathrm{C}$ to obtain the model to evaluate the reduction of canola seed germination. This model was included in the drying simulation program and the estimated germination was compared to the experimental values of germination during drying to validate the model. Canola seeds at $21 \%$ of moisture content and germination of $93 \%$ were dried at $51{ }^{\circ} \mathrm{C}$ and $61{ }^{\circ} \mathrm{C}$, and the model represented significantly the drying experiments. The aim of this study was to propose a germination model to evaluate the quality of canola seeds during the drying process and to offer the seed producers an important tool to control the drying process. The experimental data validated the objectives of the proposed drying model, optimizing the process at given conditions, managing the energy consumption, according to the minimum germination or maximum moisture content limitation for seed storage. For $51^{\circ} \mathrm{C}$, the drying time for canola seed would be about $6 \mathrm{~h}$ to maintain germination above $90 \%$ and for $61^{\circ} \mathrm{C}$, $4 \mathrm{~h}$ of drying time maintained germination up to $89 \%$.
\end{abstract}

Key words: Rapeseed, seed drying simulation, quality parameter estimation, germination.

\section{Introduction}

Canola (Brassica napus and Brassica campestris) is the third most important oilseed, especially in the modern agribusiness. In 2013, the world production was about 71 million tons; the largest producer was Canada with 17.5 million tons, and Brazil harvested 61,000 tons [1]. Canola is the breeding of rapeseed with low levels of erucic acid and glucosinolate, which are toxic compounds for human and animal feeding [2]. High composition of unsaturated fatty acids prevented health hazardous low density lipoprotein (LDL), recognized as GRAS [3].

Canola oil is also a good alternative for biodiesel production [4, 5] due to the elevated oil content (40\%-45\%), according to Refs. [6, 7].

Canola seeds are harvested at high moisture content (18\%-24\%) to prevent dehiscence [8, 9], and

Corresponding author: Armando Kazuo Fujii, Ph.D., research field: postharvest technology. immediate drying is required to maintain quality [10].

Germination and vigor maintenance should be considered for drying quality, due to correlation to the thermal stress to the seed [11].

Maintaining the seeds in hermetic tubes at constant conditions, Ellis and Roberts [12] verified that the death in the population of stored seeds at constant conditions of temperature and moisture followed the normal distribution, representing the death dispersion (Eq. (1)), defining the probit viability.

Nellist [13] presented a simplification of drying process to evaluate germination as successive steps of storage at constant conditions, and verified that seed germination decreased with time during drying or storage and was a function of initial seed germination, seed temperature and seed moisture content.

$$
G=\frac{1}{\sigma \sqrt{2 \pi}} \int_{t}^{+\infty} \exp \left[-\frac{1}{2}\left(\frac{t-\bar{t}}{\sigma}\right)^{2}\right] d t
$$

where, $G$ : germination (decimal), $G=\mathrm{f}\left(G_{0}, T, M\right)$; $T$ : 
temperature $\left({ }^{\circ} \mathrm{C}\right)$; $M$ : moisture content (\%); $\bar{t}$ : time for $G=0.5$ (min); $\sigma$ : standard deviation (min).

Andreoli [14] applied to longevity of maize seeds, a simplification of the original equation proposed by Refs. [12, 15] studied the equation from Andreoli [14] for the physiological potential of artificially aged maize seeds.

This approach was used for drying process by Daniel et al. [16] and Oyekale et al. [17] for maize. Butler et al. [18] applied probit analysis for Digitalis purpurea and Soltani [19] tested with Haloxylon persicum. Pozitano and Usberti [20] obtained good relationship for controlled deterioration in grass seeds, using the theory of probit analysis and Surki et al. [21] applied for soybean viability. Babiker et al. [22] concluded that controlled conventional drying process resulted in better viability, compared to alternative methods, such as silica-gel or sun drying. Gürsoy et al. [23] tested germination as maize quality in microwave drying.

From the modified gamma distribution (from where Eq. (1) is originated), a simplification of the viability distribution (application of probit analysis [12]), the variable $X$ (standardized normal deviate variable) was introduced in Eq. (2), and Eq. (3) is obtained.

$$
\begin{gathered}
X=\frac{(t-\bar{t})}{\sigma} \\
G=\frac{\operatorname{erfc}(X)}{2}
\end{gathered}
$$

The deviation may be expressed as in Eq. (4), and the methodology of Ellis and Roberts [12] may be followed.

$$
\sigma=e^{a-b^{*} T-c^{*} \ln (M)}
$$

where, $T$ : temperature $\left({ }^{\circ} \mathrm{C}\right) ; M$ : moisture content (\%); $a, b, c$ : seed coefficients.

In the simulation program, each $d t$ loop, a new value of $X$ was determined, and $G$ is obtained by the complementary error function $(\operatorname{erfc}(X))$.

For $t=t_{0}, G_{0}=\operatorname{erfc}\left(X_{0}\right) / 2$, and from Eq. (2), for time $t_{1}=t+d t$, the variable $X_{1}$ comes to:

$$
X_{1}=X_{0}+\frac{t_{1}}{\sigma}
$$

The objectives of the research were: (1) to obtain a germination model to evaluate the quality of canola seeds during the drying process; (2) to test the model for lower drying temperatures; (3) to offer to the seed producers an alternative to optimize the drying process with the germination model, preventing excessive drying time and germination reduction.

\section{Materials and Methods}

\subsection{Canola Seeds}

Canola seeds were harvested with 21\% moisture and $93 \%$ of germination.

\subsection{Sealed Storage}

Sealed storage tests were the main experiments conducted to evaluate the germination loss in canola seeds as a function of temperature and time of exposure. Sealed aluminum pouches (a three-layer laminate of $0.0122 \mathrm{~mm}$ polyester film, laminated to $0.0089 \mathrm{~mm}$ aluminum foil, which was laminated to a $0.0762 \mathrm{~mm}$ modified polypropylene film), containing approximately $50 \mathrm{~g}$ of canola seeds, were conditioned in water-bath at constant conditions of temperature and moisture content.

The seeds in sealed pouches were treated at 50, 60 and $70{ }^{\circ} \mathrm{C}$, during different time interval, using a controlled temperature water-bath $(20 \mathrm{~L}$ capacity and $\pm 1.0^{\circ} \mathrm{C}$ precision from Thomas Scientific).

\subsection{Analytical Methods}

Germination tests were based on the ISTA rules [24] of seed germination tests, $10 \mathrm{~d}$ after the treatments. Facilities of the Michigan Seed Foundation were used to perform all the canola seed germination tests.

Three replications of 100 seeds were placed on moistened blotter papers over germination trays and kept at $22{ }^{\circ} \mathrm{C}$. The first count of normal seedlings was 
made after $5 \mathrm{~d}$, and the second count, after $10 \mathrm{~d}$.

The moisture content was determined in an air circulating oven at $130^{\circ} \mathrm{C}$ for $4 \mathrm{~h}$ [25].

\subsection{Simulation and Validation}

A Fortran drying simulation program modified by Maier [26] was used. Through the probit analysis, using Eq. (3), $G$ is converted to $X$. From the sealed storage, the parameters of Eq. (4) were determined and Eq. (5) gave the value of $X$ of next step of drying simulation, and new $G$ is obtained. The simulation may be stopped at moisture content of $8 \%$ (final moisture content $\left(M_{f}\right)$ ) or at minimum germination $\left(G_{f}\right)$.

\subsection{Experimental Drying}

An oil barrel of $45 \mathrm{~cm}$ in diameter, holding approximately $100 \mathrm{~kg}$ of seeds when filled to a depth of $1.0 \mathrm{~m}$, was used as canola seed dryer with airflow of $0.5 \mathrm{~m} / \mathrm{s}$ being provided by a centrifugal fan. The temperature of the drying air $\left(51^{\circ} \mathrm{C}\right.$ and $\left.61{ }^{\circ} \mathrm{C}\right)$ was controlled by a system of electrical heaters and measured by thermocouples each $20 \mathrm{~cm}$ depth.

\section{Results and Discussion}

The results from the sealed storage tests for the determination of the parameters of the Eq. (4) were presented in Table 1.

The parameters of Eq. (4) were determined from the sealed storage experimental data, resulting in Eq. (6). The linear regression presented correlation $R^{2}=0.899$ [25].

$$
\sigma=e^{13.55-0.12 * T-0.72 * \ln (M)}
$$

The experimental and estimated sigma values were represented in Fig. 1. Sigma is standard deviation of Eq. (1).

Eq. (6) was introduced to the given Fortran program to simulate the drying process for $10 \mathrm{~h}$, resulting in the germination values for the temperature and moisture conditions at the moment of simulation step. From the simulation and validation tests, the experimental and estimated values of temperature, moisture content and germination of canola seeds after drying were presented in Fig. 2.

From the experiments, drying canola seeds were at temperature of $51{ }^{\circ} \mathrm{C}$, after $390 \mathrm{~min}$, the average moisture content was $5.9 \%$, resulting in $91.6 \%$ of final germination; for drying temperature of $61{ }^{\circ} \mathrm{C}$, after $330 \mathrm{~min}$, the average moisture content was $4.1 \%$ and the final germination was at $87.7 \%$.

Table 1 Germination of canola seeds in sealed storage at 50,60 and $70{ }^{\circ} \mathrm{C}$.

\begin{tabular}{|c|c|c|c|c|c|c|c|c|}
\hline \multicolumn{9}{|c|}{ Germination of canola seeds in sealed storage at } \\
\hline \multicolumn{3}{|c|}{$50{ }^{\circ} \mathrm{C}$} & \multicolumn{3}{|c|}{$60^{\circ} \mathrm{C}$} & \multicolumn{3}{|c|}{$70^{\circ} \mathrm{C}$} \\
\hline $\begin{array}{l}\text { Moisture } \\
(\%)\end{array}$ & $\begin{array}{l}\text { Time } \\
\text { (min) }\end{array}$ & $\begin{array}{l}\text { Germination } \\
\text { (\%) }\end{array}$ & $\begin{array}{l}\text { Moisture } \\
(\%)\end{array}$ & $\begin{array}{l}\text { Time } \\
\text { (min) }\end{array}$ & $\begin{array}{l}\text { Germination } \\
(\%)\end{array}$ & $\begin{array}{l}\text { Moisture } \\
(\%)\end{array}$ & $\begin{array}{l}\text { Time } \\
\text { (min) }\end{array}$ & $\begin{array}{l}\text { Germination } \\
(\%)\end{array}$ \\
\hline 7.3 & 10 & 94.3 & 12.5 & 30 & 91.3 & 7.3 & 7.2 & 67.0 \\
\hline 7.3 & 270 & 29.3 & 12.5 & 120 & 74.3 & 7.3 & 12 & 74.7 \\
\hline 7.3 & 420 & 25.0 & 12.5 & 180 & 52.3 & 7.3 & 37 & 54.0 \\
\hline 12.5 & 10 & 93.7 & 12.5 & 210 & 50.7 & 13.8 & 2.9 & 90.3 \\
\hline 12.5 & 210 & 72.7 & 13.8 & 120 & 50.3 & 13.8 & 7.2 & 56.3 \\
\hline 12.5 & 360 & 48.3 & 13.8 & 150 & 46.3 & 13.8 & 57 & 8.7 \\
\hline 13.8 & 180 & 82.0 & 13.8 & 180 & 25.0 & 14.2 & 2.9 & 87.0 \\
\hline 13.8 & 240 & 52.3 & 14.2 & 40 & 94.0 & 14.2 & 7.2 & 79.7 \\
\hline 13.8 & 420 & 21.0 & 14.2 & 60 & 92.3 & 14.2 & 17 & 48.0 \\
\hline 16.0 & 60 & 94.0 & 14.2 & 90 & 78.7 & 14.2 & 27 & 19.3 \\
\hline 16.0 & 120 & 93.7 & 16.7 & 40 & 92.0 & & & \\
\hline \multirow[t]{2}{*}{16.0} & 210 & 74.0 & 16.7 & 50 & 82.7 & & & \\
\hline & & & 16.7 & 60 & 76.0 & & & \\
\hline
\end{tabular}




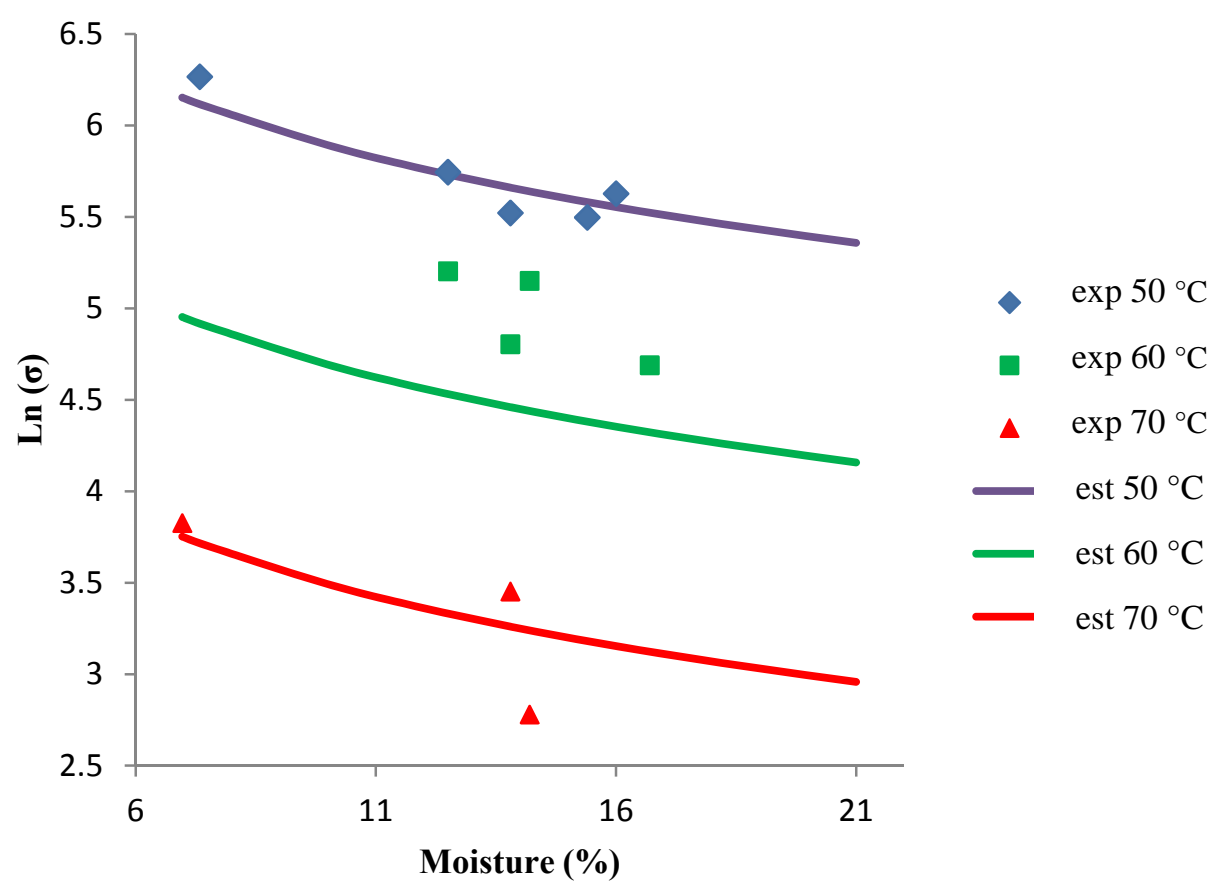

Fig. 1 Experimental and estimated values of sigma.

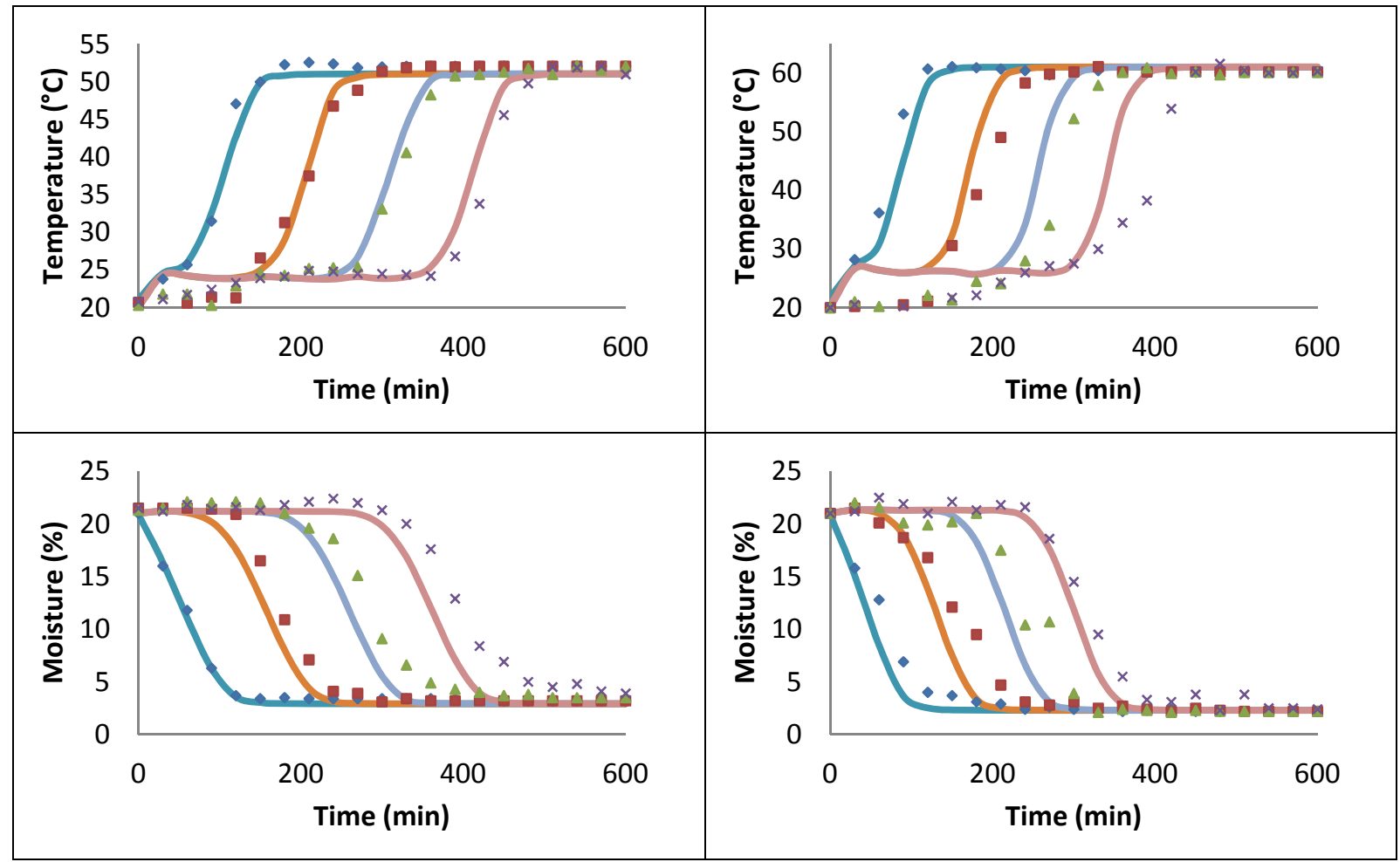




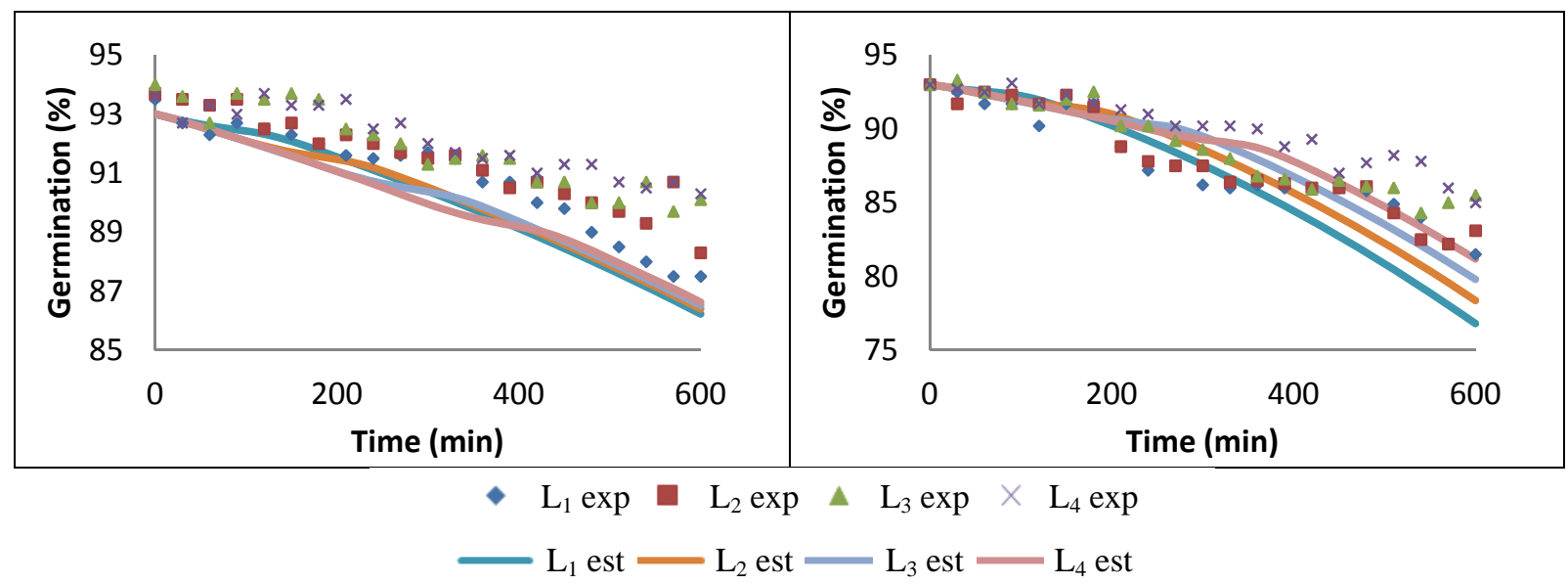

Fig. 2 Temperature, moisture and germination at four layers of canola seed drying process at $51^{\circ} \mathrm{C}$ (left) and $61{ }^{\circ} \mathrm{C}$ (right side). The layer $1\left(\mathrm{~L}_{1}\right)$ is positioned on the dryer plenum.

Applying the model of Eq. (6), the results of experimental data from Corrêa et al. [27] and Kumar et al. [28] at 30, 40 and $50^{\circ} \mathrm{C}$ were analogous.

Kumar et al. [28] obtained $96 \%$ of germination, drying at $30{ }^{\circ} \mathrm{C}, 92 \%$ at $40{ }^{\circ} \mathrm{C}$ and $90 \%$ at $55^{\circ} \mathrm{C}$, and this proposed germination model (Eq. (6)) resulted in $93 \%, 92 \%$ and $87 \%$, respectively.

Corrêa et al. [27] drying canola seed at $30{ }^{\circ} \mathrm{C}$ and $40{ }^{\circ} \mathrm{C}$, obtained final germination of $94 \%$ and this proposed model presented germination of $92 \%-93 \%$ at the same temperature.

The experimental drying and simulation was extended up to $10 \mathrm{~h}$, however, the maximum recommended moisture content for long storage period of canola seeds would be $8 \%$.

Drying at $51{ }^{\circ} \mathrm{C}$, the average temperature was $40.2{ }^{\circ} \mathrm{C}$ after drying canola seed for $6 \mathrm{~h}$ and the germination maintained at $91 \%$. If drying at $61{ }^{\circ} \mathrm{C}$, for $4 \mathrm{~h}$, the average temperature was $43.2^{\circ} \mathrm{C}$, and final germination was $89 \%$.

If the drying has to be concluded only after the top layer $\left(\mathrm{L}_{4}\right)$ reach the air temperature, for drying at $51^{\circ} \mathrm{C}$, the final germination was $88.4 \%$ and for $61^{\circ} \mathrm{C}$, the drying process results in $85 \%$ of germination, reaching $5 \%$ of moisture content, and the seeds may suffer breakage during handling.

These situations present an important tool for the seed drying operators for any species to predict drying time to prevent germination reduction, determining the parameters for the proposed model.

The seed grower may control the drying process through a simple computer program or a worksheet developed for several drying conditions, introducing the drying conditions as input data to the model of sealed storage model for the selected seed species, and finish the process when the final moisture or the minimum germination is achieved.

The estimated germination for drying at $51{ }^{\circ} \mathrm{C}$ enhances the validation of the experimental data, for the safe viability the seed drying process. Even for drying process at $61{ }^{\circ} \mathrm{C}$, assuming that the final moisture content is of $8 \%$, the model achieved the proposed objective.

\section{Conclusions}

The proposed model for canola seed quality adjusted very well the experimental data, for a wide range of drying conditions.

The model of seed quality to evaluate germination losses in drying process is an important tool for the seed companies.

Seed germination evaluation during drying is a useful tool for seed quality preservation achieved by a simple model to estimate the germination for the given experimental drying conditions.

\section{References}

[1] Embrapa. 2014. “Canola in Numbers.” Accessed July 19, 
2015. www.cnpt.embrapa.br/pesquisa/economia/2014 _04_CANOLAnumeros.pdf.

[2] Kumar, S., Chauhan, J. S., and Kumar, A. 2010. "Screening for Erucic Acid and Glucosinolate Content in Rapeseed-Mustard Seeds Using Near Infrared Reflectance Spectroscopy.” J. Food Sci. Technol. 47 (6): 690-2.

[3] Lin, L., Allemekinders, H., Dansby, A., Campbell, L., Durance-Tod, S., Berger, A., and Jones, P. J. 2013. "Evidence of Health Benefits of Canola Oil." Nutr. Rev. 71 (6): 370-85.

[4] Firrisa, M. T., Van Duren, I., and Voinov, A. 2014. "Energy Efficiency for Rapeseed Biodiesel Production in Different Farming Systems.” Energy Effic. 7 (1): 79-95.

[5] Silva, L. F. L. 2013. "Viability of Canola, Forage Turnip and Sweet Potato Crops for the Production of Biofuels in Southern Minas Gerais.” M.Sc. thesis. http://repositorio.ufla.br/jspui/handle/1/620.

[6] Khattab, R., Rempel, C., Suh, M., and Thiyam, U. 2012. "Quality of Canola Oil Obtained by Conventional and Supercritical Fluid Extraction.” Am. J. Anal. Chem. 3 (12A): 966-76.

[7] Rossato, R., Prete, C. E. C., De Castro, C., Tomm, G. O., Leite, R. S., Mandarino, J. M. G., De Araújo, P. M., and De Carvalho, C. G. P. 2013. "Predicting Rapeseed Oil Content with Near-Infrared Spectroscopy." Pesqui. Agropecuária Bras. 48 (12): 1601-5.

[8] Albrecht, L. P., Krenchinski, F. H., Placido, H. F., Bomm, M. A. R., Kunz, V. L., Korber, Â. H. C., and Bieler, R. R. 2013. "Canola Desiccation at Different Stages of Pods Maturation.” Brazilian Journal of Herbicides 12 (2): 143-50. (in Portuguese)

[9] Kadkol, G. 2009. "Brassica Shatter-Resistance Research Update.” In Proceedings of the 16th Australian Research Assembly on Brassicas Conference, Ballarat Victoria.

[10] Sathya, G., Jayas, D. S., and White, N. D. G. 2009. "Safe Storage Guidelines for Canola as the Seeds Slowly Dry.” Can. Biosyst. Eng. 51: 329-38.

[11] Thuzar, M., Puteh, A. B., Abdullah, N. A. P., Lassim, M. B. M., and Jusoff, K. 2010. "The Effects of Temperature Stress on the Quality and Yield of Soya Bean.” J. Agric. Sci. 2 (1): 172-9.

[12] Ellis, R. H., and Roberts, E. H. 1980. "Improved Equations for the Prediction of Seed Longevity.” Ann. Bot. 45 (1): 13-30.

[13] Nellist, M. E. 1978. Safe Temperatures for Drying Grain. Accessed June 10, 2014. National Institute of Agricultural Engineering. https://books.google.com.br/ books/about/Safe_Temperatures_for_Drying_Grain.html ?id=C4zzGgAACAAJ\&redir_esc=y.

[14] Andreoli, C. 2004. "Simplification of Viability Equation to Predict Seed Longevity of Corn and Soybean."
Brazilian Agricultural Research 39 (9): 911-7. (in Portuguese)

[15] Gazola, S., Scapim, C. A., De Lucca e Braccini, A., De Araujo, Â. M. M., Do Amaral Júnior, A. T., and Vivas, M. 2015. "Probit Regression to Estimate the Physiological Potential of Hybrid Maize Seed.” J. Seed Sci. 37 (1): 33-9.

[16] Daniel, I. O., Oyekale, K. O., Ajala, M. O., Sanni, L. O., and Okelana, M. O. 2009. "Physiological Quality of Hybrid Maize Seeds during Containerized-Dry Storage with Silica Gel.” Afr. J. Biotechnol. 8 (2): 181-6.

[17] Oyekale, K. O., Daniel, I. O., Ajala, M. O., and Sanni, L. O. 2012. "Potential Longevity of Maize Seeds under Storage in Humid Tropical Seed Stores.” Nat. Sci. 10 (8): 114-24.

[18] Butler, L. H., Hay, F. R., Ellis, R. H., Smith, R. D., and Murray, T. B. 2009. "Priming and Re-drying Improve the Survival of Mature Seeds of Digitalis purpurea during Storage.” Ann. Bot. 103 (8): 1261-70.

[19] Soltani, A. 2011. "Seed Germination Response of Haloxylon persicum (Chenopodiaceae) to Different Hydrothermal Conditions and Sand Burial Depths.” Casp. J. Env. Sci. 9 (2): 211-21.

[20] Pozitano, M., and Usberti, R. 2009. "Seed Controlled Deterioration of Three Interspecific Elephant Grass $\times$ Pearl Millet Hybrids.” Rev. Bras. Zootec. 38 (3): 428-34.

[21] Surki, A. A., Sharifzadeh, F., and Afshari, R. T. 2012. "Effect of Drying Conditions and Harvest Time on Soybean Seed Viability and Deterioration under Different Storage Temperature.” Afr. J. Agric. Res. 7 (36): 5118-27.

[22] Babiker, A. Z., Dulloo, M. E., El Balla, M. A. M., and Ibrahim, E. T. 2010. "Effects of Low Cost Drying Methods on Seed Quality of Sorghum bicolor (L.) Monech.” Afr. J. Plant Sci. 4 (9): 339-45.

[23] Gürsoy, S., Choudhary, R., and Watson, D. G. 2013. "Microwave Drying Kinetics and Quality Characteristics of Corn.” Int. J. Agric. Biol. Eng. 6 (1): 90-9.

[24] "Introduction to the ISTA Rules.” Int. Rules Seed Test 2017: 1-12. doi:10.15258/istarules.2017.i.

[25] Fujii, A. K. 2007. "Drying Simulation of Canola Seeds (Brassica napus) with Prediction of Germination.” Ph.D. thesis, University of Campinas. http://libdigi.unicamp.br/ document/?code=vtls000417636.

[26] Maier, D. E. 1992. "The Chilled Aeration and Storage of Cereal Grains.” Ph.D. thesis, Michigan State University.

[27] Corrêa, P. C., Martins, J. H., and Christ, D. 1999. "Thin Layer Drying Rate and Loss of Viability Modelling for Rapeseed (Canola).” J. Agric. Eng. Res. 74 (1): 33-9.

[28] Kumar, R., Jain, S., and Garg, M. K. 2010. "Drying Behaviour of Rapeseed under Thin Layer Conditions.” J. Food Sci. Technol. 47 (3): 335-8. 